\title{
LIVING ASWAJA SEBAGAI MODEL PENGUATAN PENDIDIKAN ANTI RADIKALISME DI PESANTREN
}

\author{
Ach Rofiq \\ Institut IImu Keislaman Annuqayah Sumenep \\ zerorofiq@gmail.com
}

\begin{abstract}
ABSTRAK
Pesantren adalah salah satu lembaga pendidikan Islam yang fokus pada studi doktrin Islam. Namun, oleh sebagian pihak, pesantren dituduh sebagai pusat pendidikan Islam radikal yang mempelajari doktrin Islam secara eksklusif dan kaku. Tetapi Pesantren mengklaim diri bahwa dia adalah lembaga yang melarang radikalisme dan menghindari terorisme dan kekerasan. Pesantren mengajarkan doktrin Ahlussunnah wa al-Jama'ah sebagai sarjana teologi Islam moderat yang mengacu pada al-Qur'an, hadits, dan buku-buku sarjana Islam tradisional dan meneruskan tradisi mereka sampai sekarang. Artikel ini akan menjelaskan model pendidikan deradikalisasi di pondok pesantren Annuqayah dengan living Aswaja dengan fokus masalah, menjelaskan kontribusi Living Aswaja sebagai model pendidikan Islam moderat untuk menghindari radikalisme di Annuqayah Boarding School. Artikel ini adalah penelitian kualitatif dengan pendekatan fenomenologi untuk mendapatkan deskripsi Living Aswaja sebagai model pendidikan. Hasil penelitian menggambarkan bahwa Living Aswaja adalah salah satu pendidikan Islam moderat yang dianut dalam gaya hidup sehari-hari Kiai dan Santri sebagai manifestasi pengajaran kitab-kitab karya sarjana Islam tradisional. Kiai dan para santri menerapkan ajaran Ahlussunnah wa al-Jama'ah dalam pemikiran dan tindakan seperti moderat (tawassut), keseimbangan (tawazun), toleransi (tasamuh), dan keadilan (ta'adul). Model pendidikan deradikalisme mulai menganut budaya kehidupan sehari-hari baik secara lisan maupun praktis.
\end{abstract}

Kata Kunci: Living Aswaja, Anti radikalisme, pesantren

\footnotetext{
ABSTRACT

Pesantren is one of the institutions of Islamic education that focuses on the study of Islamic doctrine. However, by some parties, pesantren are accused of being centers of radical Islamic education which study Islamic doctrine exclusively and rigidly. But the pesantren claims that it is an institution that bans radicalism and avoids terrorism and violence. The pesantren teaches the doctrine of Ahlussunnah wa al-Jama'ah as a scholar of moderate Islamic theology that refers to the Koran, hadith, and traditional Islamic scholar books and continues their tradition until now. This article will explain the
} 
model of deradicalization education in the Annuqayah boarding school with living Aswaja with a focus on the problem, explaining the contribution of Living Aswaja as a model of moderate Islamic education to avoid radicalism in the Annuqayah Boarding School. This article is qualitative research with a phenomenological approach to get a description of Living Aswaja as an educational model. The results of the study illustrate that Living Aswaja is one of the moderate Islamic education that is adopted in the daily lifestyle of Kiai and Santri as a manifestation of teaching the books of traditional Islamic scholars. The Kiai and the Santri apply the teachings of Ahlussunnah wa al-Jama'ah in thoughts and actions such as moderate (tawassut), balance (tawazun), tolerance (tasamuh), and justice (ta'adul). The educational model of deradicalism begins to embrace the culture of daily life both verbally and practically.

Keywords: Living aswaja, anti-radicalism, pesantren. 


\section{PENDAHULUAN}

Akidah al-Ahl al-sunnah wa al-Jama'ah merupakan ideologi yang tidak bisa dilepaskan dari pendidikan pesantren. Karena landasan filosofis pendidikan pesantren adalah akidah Ahlussunnah wa al-Jama'ah. Secara historis, pesantren dibangun selain sebagai media pengembangan pengetahuan keagamaan masyarakat desa, juga untuk menjadi benteng akidah Ahl al-Sunnah wal al-Jama'ah, yang pada waktu itu terancam serangan wahabisasi diprakarsai oleh King Sa'ud di berbagai belahan dunia. Oleh karena itu, pesantren dan akidah Ahlussunnah wa al-Jama'ah ibarat dua sisi mata uang yang tidak bisa dilepaskan satu sama lainnya.

Salah satu doktrin akidah Ahlussunnah wa al-Jama'ah yang sangat akrab dengan dunia pesantren adalah moderasi berpikir (wasatiyah fi al-fikr) dan moderasi dalam gerakan (wasathiyah fi al-harakah). Moderasi dalam berpikir (wasathiyah alfikr) di pesantren dibuktikan dengan konstruksi metode berpikir masyarakat pesantren yang sama-sama mampu menyeimbangkan antara teks (norma agama) yang berbasis al-Qur'an hadits dan rasio (akal) dengan basis berpikir tradisional rujukannya kepada kitab-kitab klasik hasil olah piker (ijtihad dan tafsir) para ulama' tradisonal. Sementara moderasi dalam tindakan dan perjuangan (wasathiyah al-harakah), dimanifestasikan dalam bentuk mencintai tradisi-tradisi para pendahulu dengan tanpa mengindahkan berbagai perkembangan sebagai konsekuensi dari perkembangan zaman.

Pola pikir moderat ini kemudian melandasi pendidikan pesantren mulai dari awal pendiriannya yang membuat bertahan dan bahkan mendapatkan posisi spesial di hati masyarakat pada umumnya, khususnya masyarakat pedesaan dan perkampungan di tengah maraknya isu-isu dan tindakan radikal, berupa pengeboman dan destruksi atas nama agama. Dan anehnya, pesantren yang dituduh sebagai otak dan pelaku utama dalam hal ini semua. Itu semua ketika ditelisik langsung ke dalam pesantren secara fenomenologis sangat berseberangan. Karena pesantren mulai dari awal dibangunnya tidak bisa dilepaskan dari masyarakat kecil pedesaan yang masih awam dan kental dengan tradisi dan budaya setempat, sehingga proses pelaksanaan pendidikan pun tidak bisa lepas dari kebutuhan masyarakat yang menjadi akar tradisitradisi yang berkembang, maka wajar ketika pesantren secara eksistensial dan praktikal mampu membantah tuduhan sarang teroris dan tempat mencetak teroris.

Dalam artikel ini, penulis mencoba untuk meneliti pendidikan keaswajaan dan kualitas-implikatif dalam bentuk sikap dan tindakan komunitas santri guna untuk 
menyokong pendidikan moderasi beragama dan anti radikalisme, yang awalnya secara konseptual-praktikal diajarkan di pesantren dan terbatas kepada dimensidimensi praktik ibadah formal (mahdhah). Kemudian membentuk cara berpikir moderat berupa keseimbangan kajian agama yang melibatkan aspek teks-teks normatif dan rasional. Juga tradisi-tradisi kemasyarakatan yang secara rutin dilaksanakan dan diperaktekkan di pesantren, seperti shalawatan, tahlilan, ziarah kubur, dan lain sebagainya, sebagai manifestasi praktikal pola pikir yang terbangun.

Pola pikir ini kemudian secara akademik lebih akrab dengan sebutan "living aswaja" dengan pendekatan fenomenologis, untuk mendapatkan data dan tafsiran terhadap fenomena simbolik yang ditampilkan oleh objek yaitu pendidikan pesantren yang spesifik pada objek penelitian di Pondok Pesantren Annuqayah Guluk-Guluk Sumenep Madura, kemudian menjadi sebuah kesimpulan (hipotesa), dengan titik persoalan utama yaitu bagaimana format living aswaja di Pondok Pesantren Annuqayah Guluk-Guluk Sumenep Madura? dan apa implikasinya terhadap pendidikan anti radikalisme masyarakat pesantren khususnya di sekitar Pondok Pesantren Annuqayah Guluk-Guluk Sumenep Madura ? untuk membuktikan kepada publik bahwa pesantren adalah ikon utama pencetak kader-kader yang moderat dalam beragama dan bernegara dengan teknik analisa isi (content analysis).

\section{LIVING ASWAJA DI PESANTREN}

Terminologi "living" merupakan terminologi teoritis yang akhir-akhir ini sering dipakai dalam diskursus tafsir dan hadits "Living Qur'an dan "Living Hadits". Tetapi di dalam penelitian ini, peneliti hanya mencatutnya sebagai kerangka teori tentang doktrin bahkan ideologi Aswaja yang sudah mentradisi dan menjadi nilai-nilai ideologi prilaku dan tindakan santri di pesantren.

Aswaja dan pesantren merupakan dua hal yang tidak bisa dilepaskan. Fakta historis yang tidak bisa membuat celah bagi orang-orang yang ingin memisahkan ajaran Ahlussunnah wa al-Jama'ah dari pesantren. Karena secara historis, pesantren didirikan selain sebagai bentuk kepedulian para kiai terhadap pengetahuan umat Islam Indonesia yang sangat nihil, juga untuk membentengi akidah Ahlussunnah wa al-Jama'ah di Indonesia dari wahabisasi yang sudah mulai menyebar.

Aswaja merupakan singkatan dari ajaran akidah Ahlussunnah wa al-Jama'ah, yaitu salah satu ajaran akidah yang merujuk pada doktrin aliran kalam yang digagas oleh Abu Hasan al-Asy'ari dan Abu Mansur al-Maturidi. Secara terminologis Aswaja 
adalah ajaran yang merujuk doktrin dan tradisi yang yang dilakukan oleh Rasulullah Saw, sahabat, dan para ulama' salaf serta tradisi-tradisi yang diakui oleh mereka. Aswaja merupakan salah satu doktrin akidah yang kemudian menjadi sebuah metode berfikir dan terus berkembang menjadi sebuah ideologi, dengan proses sejarah yang sangat panjang. Secara sederhana, ajaran aswaja oleh KH. Hasyim Asy'ari kemudian dirumuskan dengan ajaran yang secara akidah mengikuti akidah aliran Asy'ariyah dan al-Maturidiyah, fiqih mengadopsi pendapat ulama' madzhab fiqh yang empat (Hanafi, Maliki, Syafi'ie, dan Hambali), sementara dalam konteks akhlak tasawuf merujuk pada tasawuf Imam al-Ghazali dan Imam al-Junaid al-Baghdadi.

Aswaja di Indonesia di bawa oleh para Wali Songo (1330H) dan ulama'-ulama' pendiri pesantren. Metode dakwah dan sikap serta tindakan wali songo ketika berdakwah tidak lepas dari prinsip berpikir (manhaj al-fikr) dan cara berbuat (manhaj al-harakah) aswaja yang sarat dengan akulturasi antara doktrin dan budaya di mana mereka tinggal dan berdakwah. Sunan Kalijaga dengan wayang kulitnya, Sunan Giri dengan gamelannya, dan lain sebagainya. Sehingga pada perkembangannya, doktrin aswaja inherent dengan tradisi dan budaya setempat. Muslim Sunni Indonesia perkembangannya, mentradisikan dan suka tahlilan, istighatsah, shalawatan, ziarah kubur, talqinan, percaya adanya syafa'at dan sampainya doa dengan tawassul, yang kemudian mampu membuat pemeluk Hindu dan Budha sebagai agama yang berkembang sebelumnya, tertarik dan memeluk agama Islam.

Selain doktrin-doktrin khusus tentang seputar akidah, Aswaja juga mengapresiasi tradisi lokal Nusantara yang berkembang saat itu, tidak mudah membid'ahkan bahkan mengkafirkan pelakunya. Justru mencarikan legitimasi Islam senyampang tidak mengandung unsur kemusyrikan. Sehingga serangan-serangan yang dilakukan oleh kelompok-kelompok Modernis yang menyerukan kembali kepada ajaran al-Qur'an-Hadits dan menjauhi tahayul, bid'ah, dan khurofat tidak mendapatkan respon masyarakat Islam walaupun lebih dahulu diperjuangkan oleh para tokohtokohnya.

Keberislaman ala wali songo ini kemudian dilanjutkan oleh para ulama' dengan mendirikan pesantren-pesantren di semenanjung Indonesia. Dan juga mendirikan organisasi besar yang sampai sekarang terus berkembang pesat, yaitu Nahdhatul Ulama' (NU) yang secara doktrin dan tradisi merujuk kepada apa yang ajarkan dan dicontohkan oleh wali songo. Doktrin dan tradisi tersebut selanjutnya terus diajarkan dan ditradisikan oleh para kiai di pesantren-pesantren binaannya, bahkan kemudian 
menjadi manhaj berfikir (manhaj al-fikr) dan metode bertindak dan berjuang (manhaj al-harakah).

Aswaja sebagai kerangka berfikit (manhaj al-fikr) di pesantren dapat ditemukan dalam tradisi kajian hukum Islam (Bahtsul Masail), dengan cara musyawarah bersama santri untuk menetapkan fenomena yang belum jelas status hukumnya dengan merujuk kepada pendapat para ulama' yang diambil dari kitab-kitab klasik yang menjadi objek kajian di pondok pesantren.

Salah satu contoh yang dapat diamati bersama adalah salah satu pendiri pesantren tertua sekaligus organisasi sosial-keagamaan di Nusantara ini, yaitu $\mathrm{KH}$. Hasyim Asy'ari. Sumber pemikiran beliau tidak hanya menggunakan al-Qur'an dan Hadits, tetapi juga menggunakan kemampuan akal (rasio) dipadukan dengan realitas empirik. Cara berpikir seperti itu dinilai merujuk kepada pemikir terdahulu, yaitu Abu Hasan al-Asy'ari dan Abu Mansur al-Maturidi. Kemudian juga, sikap di dalam merespon kehidupan di dunia lewat peraktek keseimbangan antara dimensi duniawiyah dengan dimensi ukhrawiyah, dengan model berpikir moderat (tawassut) dan seimbang (tawazun). Sementara aswaja sebagai metode berbuat dan berjuang (manhaj al-harakah) di pesantren, bisa dilihat lewat respon terhadap setiap kebijakan pemerintah dan penguasa lainnya dengan cara menentukan sikap, berpartisipasi, dan mengkritisinya, bahkan menolaknya, jika dinilai salah dan tidak sesuai dengan prinsip dasar ajaran Islam lewat model berbuat secara adil (ta'adul), dan toleran (tasamuh).

Dalam konteks tradisi dan kemasyarakatan, para kiai pesantren sebagai panutan dan pembimbing hal ihwal mereka di dalam beragama dan berbudaya, tidak pernah menciptakan demarkasi bahkan penolakan yang apologistik terhadap tradisi masyarakat yang berkembang, seperti ziarah kubur, tahlilan, sholawatan, maulidan, tawassul, dan lain sebagainya. Tetapi justru mereka (para kiai) yang menjadi motor penggerak dan tonggak kebertahanan dan perkembangan semua itu. Sehingga pada perkembangannya, semua itu menjadi tradisi yang dipertahankan secara turun temurun dan menjadi kultur yang amat sangat kental di tengah-tengah masyarakat pesantren dan sekitarnya.

Semua itu tercermin dari sikap para kiai pemangku pondok pesantren yang kemudian dijadikan contoh dan ditiru oleh para masyarakat pesantren baik santri maupun masyarakat yang hidup dekat dengan pesantren-pesantren, dengan asumsi bahwa semuanya merupakan manifestasi dari ajaran agama Islam yang diserap oleh para kiai. Sebab, kiai bukan hanya pimpinan utama pemangku pondok pesantren, 
akan tetapi juga menjadi sumber referensi setiap tindak tanduk santri dan masyarakat di sekitar pesantren yang diderivasi dari seluruh gaya dan metode dakwah para wali songo, dengan didukung pengetahuan mereka terhadap ajaran Ahlussunnah wa alJama'ah.

Fenomena-fenomena historis yang pernah dicontohkan oleh para kiai pendiri pesantren, baik dalam aspek berkeyakinan, berbicara, dan berbuat merupakan manifestasi dari apa yang disebut dengan "Living Aswaja", dalam arti bahwa akidah Ahlussunnah wa al-Jama'ah di pesantren tidak hanya menjadi objek kajian yang dikutib dari berbagai sumber yang dinilai otoritatif dan sejalan dengan pemikiran dan doktrim para tokoh-tokoh aswaja, akan tetapi menjadi nilai-nilai dasar bersikap dan berbuat, sehingga berimplikasi pada cara beragama dan bernegara. Karena di dalam ajaran Ahlussunnah wa al-Jama'ah, beragama tidak perlu kemudian dengan meyingkirkan dan menganggap buruk pemeluk agama lain (truth claim). Sedangkan bernegara, harus tunduk dan mengikuti terhadap apa yang sudah menjadi keputusan dan kebijakan negara yang di tempati dan wajib membelanya manakala negara tersebut dalam suasana terjajah.

Dengan demikian, apa yang direfleksikan para kiai pendiri dan pemangku pondok pesantren merupakan bagian dari implementasi doktrin Ahlussunnah wa alJama'ah yang tidak hanya sebagai doktrin yang diikuti, akan tetapi justru menjadi ideologi yang mendarah daging dan merefleksikan gaya hidup yang sejalan dengan ideologi tersebut, sehingga menjadi toleran, moderat, adil, menyeimbangkan kepentingan dunia dan akhirat dalam bentuk ibadah dan perjuangan. Juga mampu untuk menghormati saudara-saudara seiman (ukhuwah islamiyah), saudara senegeri (ukhuwah wathaniyah), dan merasa bertanggung jawab untuk menjaga dan melestarikan negara di mana ia tinggal. Fenomena ini tidak hanya tampak dari sosok kiai seorang, tetapi juga diikuti dan dicontoh oleh masyarakat pesantren (santri) dan masyarakat sekitar baik yang memiliki ikatan dengan pesantren ataupun tidak.

\section{Living Aswaja Dan Moderasi Beragama di Pesantren Annuqayah}

Pondok pesantren Annuqayah adalah salah satu pondok pesantren yang masih berkategori pesantren tradisional. Walaupun dalam beberapa aspek telah mengalami perkembangan; seperti penyelenggaraan sistem pendidikan formal mulai dari tinggat dasar (MI) sampai ke tingkat perguruan tinggi (PT). Nilai-nilai yang menjadi ciri khas tradisionalitas sebuah pesantren adalah masih menjadikan kitab-kitab klasik sebagai objek kajian dengan sistem pembelajaran wetonan dan sorogan. Juga masih akrab 
menyelenggarakan pembelajaran sistem halqah, dan tidak pernah lekang dengan adanya modernisasi sistemik di dalamnya.

Secara geografis, Pondok pesantren Annuqayah terletak di desa Guluk-Guluk Kecamatan Guluk-Guluk Kabupaten Sumenep Madura. Didirikan pada tahun 1887an, dan sampai sekarang sudah berusia lebih dari satu abad yang lalu. Didirikan oleh salah seorang ulama' pendatang dari kota Kudus, Jawa Tengah. Kemudian mencari ilmu ke Timur Tengah (Mekkah) pulang dan kemudian bertempat tinggal di GulukGuluk Sumenep Madura.

Pondok pesantren ini didirikan atas dasar visi mewujudkan masyarakat Islam melalui proses pendidikan yang berkeimanan hakiki, bertakwa, dan berbudi pekerti luhur berlandaskan paham Ahlussunnah wa al-Jama>'ah, dengan misi; mewujudkan masyarakat madani yang berhaluan Ahlussunnah wa al-Jama>'ah, mencetak insan berkeimanan hakiki, bertaqwa, berbudi luhur, dan berprilaku sesuai dengan Ahlussunnah wa al-Jama>'ah.

Visi ini kemudian direalisasikan dalam berbagai proses pendidikan yang dilaksanakan di pondok pesantren Annuqayah pada santri yang jumlahnya kurang lebih 12 ribu yang terdiri dari santri putra dan putrid, dan terbagi ke dalam berbagai komplek atau daerah yang jumlahnya kurang lebih 11 daerah yang meliputi; Lubangsa Raya, Lubangsa Selatan, Lubangsa Utara, Kusuma Bangsa, Latee, Lubangsa Tengah, Latee Utara, Karang Jati, Sawajarin, Al-Amir, dan Kebun Jeruk dari berbagai jenjang pendidikan formal maupun non-formal yang kesemuanya di bawah nama Pondok Pesantren Annuqayah secara sistemik dan kebijakan.

Pondok Pesantren Annuqayah secara ideologis menganut aliran Ahlussunnah wa al-Jama>'ah. Secara verbal ideologi tersebut telah tercantum di dalam visi yang dijadikan pedoman penyelenggaraan pendidikan. Dan juga, secara aktual, di samping para kiai dan pemangku pesantren Annuqayah lainnya secara sanad keilmuan bersambung kepada pendiri pesantren Tebuireng Jombang dan pendiri organisasi sosial keagamaan terbesar di Indonesia (NU). Oleh karena itu, secara struktural dan kultural, ke-Aswajaan Pondok Pesantren Annuqayah sangat kuat dan tidak terbantahkan lagi secara legal maupun kultural. Maka tentunya, paradigma berpikir maupun tradisi Pondok Pesantren Annuqayah tidak bisa dilepaskan dari paradigma dan nilai yang merujuk pada ajaran Ahlussunnah wa al-Jama>'ah. 
Akidah Ahlussunnah wa al-Jamas'ah di Pondok Pesantren Annuqayah secara aplikatif diajarkan oleh para pengasuh dan kiai, melalui contoh dan teladan di dalam berbagai macam hal, baik perkataan dan perbuatan yang ditampilakan secara langsung dan spontanitas dalam konteks interaktif baik di waktu pembelajaran berlangsung atau di waktu-waktu beliau-beliau memberikan taushiah, muasyawarah dan lain sebagainya, serta turun langsung ke masyarakat dalam acara-acara halaqah ilmiah (kompolan pengajian), tahlilan, maulidan, dan acara-acara seremonial lainnya, yang secara tidak langsung menjadi media untuk mendakwahkan ajaran Ahlussunnah wa al-Jama>'ah.

Setidaknya ada beberapa varian "living Aswaja" di Pondok Pesantren Annuqayah yang menjadi tolak ukur hidupnya doktrin ideologis tersebut. Di antaranya adalah; pertama adalah integrasi ilmu pengetahuan yang diajarkan di Annuqayah melalui sistem formal berupa madrasah-madrasah dari tingkat Madrasah Ibtidaiyah (MI) sampai ke tingkat Perguruan Tinggi (PT), maupun di kegiatan-kegiatan nonformal seperti ekstrakurikuler dan lain sebagainya. Pola integrasi seperti ini sebagai manifestasi dari kerangka berpikir aswaja yaitu keseimbangan (tawazun) dan moderat( tawassuth). Kedua adalah mengapresiasi dan memperaktekkan tradisitradisi yang sarat dengan tradisi Ahlussunnah wa al-Jama>'ah, seperti talqinan di setiap pristiwa kematian, tahlilan, maulidan, dan ziarah kubur, yang menjadi tradisi dan aktivitas santri setiap pagi dan sore hari guna ngalap barokah dari para kiai sepuh penggagas dan pendahulu mereka. Ketiga; berdakwah tanpa sikap dan prilaku destruktif, tetapi dengan cara bijaksana (hikmah) dan nasehat yang baik (almau'idzah al-hasanah). Para kiai pengasuh pondok pesantren Annuqayah akrab dengan dakwah sosial keagamaan. Beliau-beliau turun langsung ke masyarakat sekitar pesantren ketika hajatan atau acara-acara seremonial yang digelar dengan tanpa wacana-wacana yang terindikasi destruktif. Beliau-beliau berdakwah berdasar pada al-Qur'an, hadits, dan pendapat para ulama' serta mengikuti cara dakwahnya Wali Songo yang bijaksana dan lemah lembut.

Dalam konteks politik, para kiai Pondok Pesantren Annuqayah sangat apresiatif dan akomodatif, baik sebagai pemeran langsung maupun pendukung. Itu bisa dilihat dari terjunnya para kiai ke kancah politik regional maupun nasional, seperti $\mathrm{KH}$. Abd. Warits (w.2016) yang pernah menjabat sebagai Anggota DPR Kabupaten, KH. A. Tsabit Khazin yang juga pernah menjabat sebagai anggota MPR pusat, K. Hazmi Basyir juga sebagai Anggota DPRD Kabupaten, dan lain sebagainya mulai dari kiai 
sepuh dan juga kiai mudanya, serta adanya partisipasi para kiai dalam acara-acara partai politik dengan ciri khas politik berbasis dakwah. Beliau menjadikan politik sebagai salah satu media untuk bisa berdakwah dan berjuang demi agama dan negara, sehingga orintasi politik beliau hanya untuk dakwah dan membantu mempertahankan Negara Kesantuan Republik Indonesia (NKRI). Kondisi ini bisa dirasakan melalui adanya perbedaan dalam mendukung partai politik dan keragaman yang tidak sampai membuatnya pecah dan komflik.

Dalam konteks ekonomi, nilai-nilai luhur yang digali dari titah para ulama' salaf yang tertuang dalam kitab-kitab klasik (kitab kuning) juga tanpak hidup dan menjadi ruh praktek perekonomian Pondok Pesantren Annuqayah. Itu semua bisa dilihat dari berdirinya unit-unit usaha dan pengembangan perekonomian masyarakat pesantren yang berbasis syari'ah yang dikutib dari kitab-kitab klasik an scih, tanpa adanya unsur ribawi dan pemerasan serta eksploitasi. Salah satu lembaga keuangan dan pengembangan ekonomi Pondok Pesantren Annuqayah dengan basis nilai-nilai tersebut adalah Unit Jasa Keuangan Syari'ah (UJKS), Bank Mini Syari'ah INSTIKA (BMSI), dan Annuqayah Bisnis Center (ABC) dalam bentuk koperasi dan toko swalayan.

Kemudian juga, dalam konteks interaksi dengan pemeluk agama lain. Para kiai Pondok Pesantren Annuqayah mengedepankan toleransi (tasa>muh) di dalam realita praktisnya. Terbukti banyak menerima para volunteer Asing yang datang ke Pondok Pesantren Annuqayah dari agama yang berbeda dengan beliau, tetapi beliau-beliau tetap terbuka, menghormati, dan menfasilitasinya sama dengan tamu-tamu yang lain yang seagama, seperti Mr. Toms (1990-an), Mr. Jhon dan Mrs. Margaret(2005-2006) yang lama berbaur dan tinggal di Annuqayah guna untuk melakukan penelitian dan pengembangan bahasa Asing (bahasa Inggris), serta kunjungan-kunjungan para volunteer lain dari berbagai negara di dunia. Fenomena ini merupakan manifestasi dari paham dan ideologis beliau-beliau yang berbasis Ahlussunnah wa al-Jama>'ah yang toleran.

Semua itu dapat dijadikan bukti hidup dan berkembangannya ideologi Ahlussunnah wa al-Jama>'ah (Living Aswaja) di Pondok Pesantren Annuqayah dengan adanya sikap akomodatif Pesantren Annuqayah terhadap setiap perkembangan yang terjadi, baik dalam konteks non-dikotamis ilmu pengetahuan dan pemanfaatan produk tekhnologi sebagai fasilitas dan media penguatan pembelajaran dan keterampilan santri yang belajar dan tinggal di pesantren. Kemudian juga, 
diresmikannya perguruan tinggi yang berbasis tekhnologi pada tahun ini 2018 yaitu Institut Sain dan Tekhnologi (IST) yang semua prodinya menyajikan pendidikan ilmu pengetahuan dan skill tekhnologis. Inovasi yang telah dilakukan pondok pesantren ini tidak lepas dari prinsip paradigmatik yang selalau menjadi pegangan pesantren yaitu merawat tradisi yang dahulu (tura>ts) yang baik dan mengadopsi segala bentuk kemajuan yang dianggap lebih baik (al-Muhafadzah ala al-Qadim al-Shalih wa al-Akhd bi al-Jadid al-Ashlah).

Fenomena tersebut tidak hanya menjadi ciri simbolik para kiai dan pondok pesantren Annuqayah secara formil saja, tetapi mampu membentuk kultur dan tradisi yang berjalan kuat dan terus hidup. Santri dengan segala tradisi dan kultur yang ada di pesantren sebagai refleksi kepribadian sang kiai, secara otomatis dapat mencontoh dan memperaktekkan semua itu di dalam kehidupan sehari-hari, baik melalui kajiankajian kitab-kitab klasik yang dianggap otoritatif di kalangan penganut Ahlussunnah wa al-Jama'ah maupun sikap dan tindakan para kiai dalam waktu 24 jam di pesantren, serta beberapa karya kiai Pondok Pesantren Annuqayah yang sebagiannya sudah bisa diakses dengan mudah oleh santri dan alumni.

Dengan demikian, akidah Ahlussunnah wa al-Jama>'ah yang secara riil tanpak hidup (living) dan menjadi nilai-nilai luhur di dalam proses penyelenggaraan pendidikan, berbudaya, berpolitik, ekonomi, dan lain sebagainya, baik dalam konteks kesantrian dan masyarakat sekitar pesantren serta alumni. Dengan itu, santri dan alumni serta masyarakat dengan mudah bisa mengakses dan mempelajari prinsipprinsip ajaran Ahlussunnah wa al-Jama>'ah melalui contoh dan praktek serta kepribadian yang tanpak dari sosok kiai dan para pemangku pondok pesantren. Implikasinya kemudian secara tidak langsung mengakar dan menjadi pola pikir setiap alumni yang tersebar di berbagai daerah dan kota di Nusantara ini berupa respon tegas mereka untuk menolak pendidikan radikal dan aksi terorisme yang akhir-akhir ini marak terjadi.

Kondisi ini kemudian diperkuat dengan terbentuknya Ikatan Alumni Annuqayah yang sering disingkat dengan IAA di berbagai daerah dan kota dalam negeri, yang salah satunya diisi dengan program kajian-kajian kitab klasik dan simposium ilmiah keagamaan oleh para kiai dan pengasuh pondok pesantren Annuqayah secara langsung, sehingga proses pendidikan moderasi dalam berbagai aspek khususnya di dalam beragama akan terus menguat dan menjadi kokoh baik di pesantren sendiri dan di luar pesantren. 
Dari berbagai fakta dan fenomena tersebut di atas dapat menjadi bukti kuat bahwa living Aswaja dalam konteks pendidikan, sosio-politik, sosio-ekonomi, dan sosial budaya dalam bentuk contoh dan tradisi yang berjalan tidak akan sedikit pun memberikan peluang masuknya paham-paham radikal yang berujung pada aksi-aksi teroris dan ekstrimis. Karena segenap bentuk penyelenggarakan pendidikan dan contoh pola hidup para kiai dan para pemangku pesantren merupakan cermin dari ideologi Ahlussunnah wa al-Jama'ah yang kokoh, cair, dan membumi.

\section{SIMPULAN}

Dari data-data yang dipaparkan di atas, maka dapat ditarik kesimpulan bahwa living aswaja di Pondok pesantren Annuqayah dapat ditelaah melalui sikap dan prilaku para kiai dalam setiap saat baik yang berhubungan langsung dengan pendidikan di pesantren maupun kegiatan-kegiatan sosial kemasyaratan.

Pola sikap yang ditampilkan oleh para kiai di Pondok Pesantren Annuqayah Guluk-Guluk Sumenep Madura merupakan manifestasi ideologi beliau-beliau yang merujuk kepada ajaran Ahlussunah wa al-Jama'ah yaitu toleran (tasamuh), moderat (tawassuth), keseimbangan (tawa>zun), dan berkeadilan (ta'a>dul) yang tercermin dalam konteks pendidikan di pesantren, di kancah perpolitikan regional maupun nasional, konteks ekonomi, dan sosial kemasyarakatan. Ideologi yang terurai dalam bentuk sikap dan perbuatan ini yang kemudian disebut dengan "living Aswaja".

Living Aswaja di Pondok Pesantren Annuqayah yang tanpak dari sosok pribadi setiap pengasuh baik secara verbal maupun tindakan faktual dengan mudah menjadi objek belajar para santri dan alumni. Mereka dengan mudah mencontoh dan menperaktekkan apa yang dicontohkan oleh para kiai baik secara langsung maupun tidak langsung seperti melalui karya dan kajian-kajiannya.

Living Aswaja yang kuat dan mengakar di Pondok pesantren Annuqayah ini bisa menjadi temeng kuat dan kokoh untuk membentengi santri, alumni, dan masyarakat dari paham-paham radikal yang berujung aksi terorisme yang marak terjadi. Sikap dan prilaku para kiai dan pengasuh pesantren Annuqayah menjadi salah satu model pendidikan anti radikalisme di pondok pesantren dan mampu untuk menjawab tuduhan miring para rival pesantren yang sering mengkambing hitamkan pesantren sebagai salah satu lembaga sarang teroris. 


\section{DAFTAR PUSTAKA}

Al-'Asyfarayini, 1988. Abu al-Mudzaffar . Al-Tabshir fi al-Din. Beirut: Dar al-Kutub alIlmiyah

Al-Buthi, Muhammad Said Ramadhan. 1990, Al-Salafiyah Marhalah Zamaniyah Mubarakah la Madzhab Islamy. Damaskus: Dar al-Fikr

Bruinessen, Martin van. 1994, "Pesantren and Kitab Kuning: Maintenance and Continuation of a Tradition of Religious Learning" in Wolfgang Marschall (ed.), Texts from the Islands: Oral and written traditions of Indonesia and the Malay world: Ethnologica Bernica. Berne: University of Berne

Dhofier, Zamakhsyari . 2015, Tradisi Pesantren; Studi Pandangan Hidup Kyai dan Visinya Mengenai Masa Depan Indonesia, Edisi Revisi. Jakarta: LP3ES

Hasan, M. Afifi . 2017, Mutiara Annuqayah: Menegaskan Khidmah Kependidikan di Annuqayah. Sumenep: INSTIKA Press

Muzadi, Abdul Muchit. 2007, NU dalam Perspektif Sejarah dan Ajaran. Surabaya: Khalista

Sukamto. 1999, Kepemimpinan Kiai dalam Pesantren. Jakarta: Pustaka LP3ES

Tim Aswaja NU Center PWNU Jawa Timur. 2016, Khazanah Aswaja; Memahami, Mengamalkan, dan Mendakwahkan Ahlussunnah wa al-Jama'ah. Surabaya: Aswaja NU Center PWNU Jatim Press

Yusuf, Muhammad. 2007, Pendekatan Sosiologi dalam Penelitian Living Qur'an dan tulisan Suryadi, Dari Living Sunnah ke Living Hadits, dalam buku bunga rampai M. Yusuf, dkk. "Metodologi Penelitian Living Qur'an dan Hadits.Yogyakarta: TERAS

Zuhairini, dkk. 1992, Sejarah Pendidikan Islam. Jakarta: Bumi Aksara 